\title{
Selective ipso-Nitration of tert-Butylcalix[4]arene Tripropylether
}

\author{
Parviz Rashidi-Ranjbar*, Saeed Taghvaei-Ganjali, Behrouz Shaabani and Karim Akbari \\ Department of Chemistry, Faculty of Science, Tehran University, Tehran, Iran \\ Fax: +98-21-6405141, E-mail: ranjbar@khayam.ut.ac.ir
}

Received: 22 April 2000 / Accepted: 29 May 2000 / Published: 10 July 2000

\begin{abstract}
An improved selective ipso-nitration of the tripropoxy derivative of tertbutylcalix[4]arene at the upper rim is described. The synthesized products are key intermediates for construction of molecular receptors based on calixarenes.
\end{abstract}

Keywords: Ipso-nitration, calixarenes.

\section{Introduction}

Calix[4]arenes have attracted considerable interest as building blocks for constructing selective host molecules [1]. Upper rim functionalised compounds can be obtained in a multi-step procedure from suitably substituted precursors [2]. Mono and dinitrated calix[4]arene are especially useful for this purpose. Several methods have been reported for selective substitution of nitro groups at the upper rim [35]. Selective ipso-nitration of partial ethers has only been described for a few ethers of tertbutylcalix[4]arene [6-9]. In this paper we report the selective substitution of one or two nitro group(s) by direct replacement of tert-butyl group(s) via an ipso-aromatic nitration. These compounds afford important starting materials for the construction of molecular receptors based on calixarenes.

\section{Results and Discussion}

The cone conformation of 5,11,17,23-tetra-tert-butyl-25-hydroxy-26,27,28-tripropoxycalix[4]arene (1) reacts with 10 eq. of $63 \% \mathrm{HNO}_{3}$ in a mixture of dichloromethane and glacial acetic acid in less than 5 min. to afford the 23-mononitro calix(4)arene 2 in $85 \%$ yield. Compared to the published procedure [7], the present method offers both milder reaction conditions and an improved yield. In the ${ }^{1} \mathrm{H}-\mathrm{NMR}$ spectrum of 2 , the aromatic meta protons in the nitrated phenolic ring shift downfield from $\delta 5.41$ (in 1) to $\delta 7.22$ (in 2 ), and the protons ortho to the nitro group appears at $\delta 8.06$. The ${ }^{1} \mathrm{H}-\mathrm{NMR}$ spectrum of 
2 exhibits two doubles of doublets signals for the bridge methylene protons, indicating the symmetrical structure of 2.

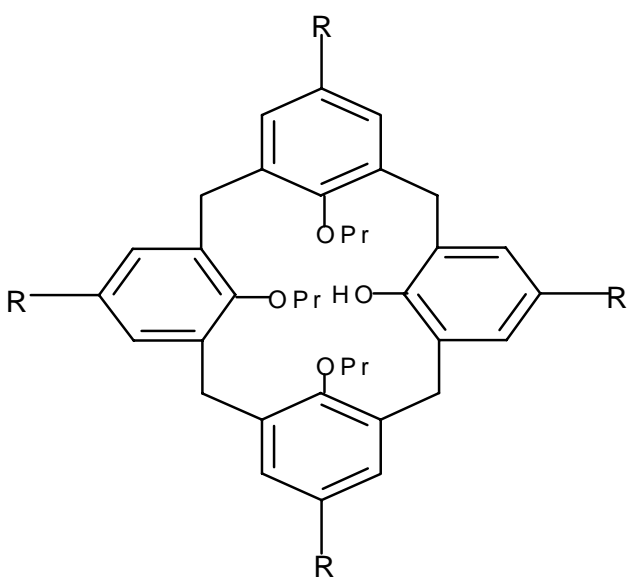

1: $R=$ tert-butyl

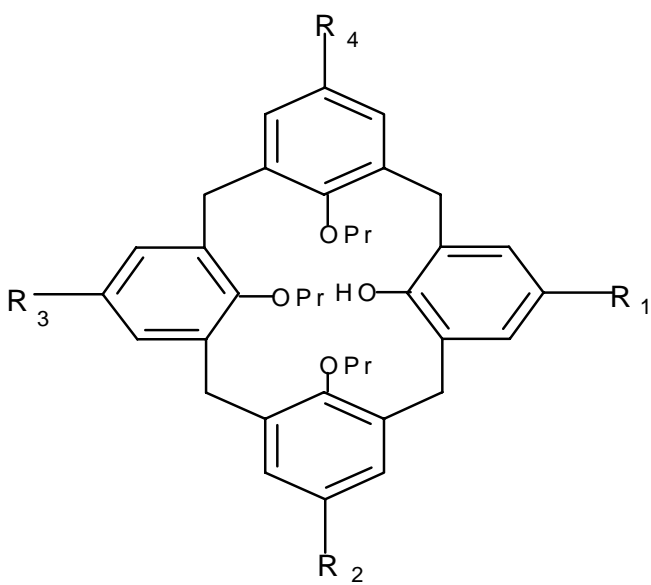

2: $\mathrm{R}_{1}=\mathrm{NO}_{2}, \mathrm{R}_{2}=\mathrm{R}_{3}=\mathrm{R}_{4}=$ tert-butyl

3: $\mathrm{R}_{1}=\mathrm{NO}_{2}, \mathrm{R}_{3}=\mathrm{NO}_{2}, \mathrm{R}_{2}=\mathrm{R}_{4}=$ tetr-butyl

4: $\mathrm{R}_{1}=\mathrm{NO}_{2}, \mathrm{R}_{2}=\mathrm{NO}_{2}, \mathrm{R}_{3}=\mathrm{R}_{4}$ = tert-butyl

\section{Figure 1.}

Treatment of 1 with 10 equivalents of $63 \% \mathrm{HNO}_{3}$ for $5 \mathrm{~min}$. in dichloromethane and in presence of $\mathrm{Ac}_{2} \mathrm{O}$, afforded the dinitro compounds 3 and $\mathbf{4}$ in a ratio of $3: 1$, judged from the ${ }^{1} \mathrm{H}-\mathrm{NMR}$ of the crude reaction mixture. The spectrum of $\mathbf{3}$ exhibits two doublets of doublets for the bridge methylene protons, indicating a central plane of symmetry. The spectrum of $\mathbf{4}$ exhibits four doublets of doublets signals for the bridge methylene protons indicating an asymmetric molecule. Symmetrical dinitro derivatives of calix[4] arene have been synthesized from the diether precursors [3], however by the present procedure the chiral dinitro derivative 4 is obtained. This compound could be used as a starting material to build up chiral hosts based on calix[4]arene to mimic the enzyme functions [1].

\section{Experimental}

\section{General}

Melting points are taken on a Büchi SMP-20 apparatus and are uncorrected. ${ }^{1} \mathrm{H}-\mathrm{NMR}$ and ${ }^{13} \mathrm{C}-\mathrm{NMR}$ spectra were recorded on a Bruker $\mathrm{AM}-400 \mathrm{MHz}$ in $\mathrm{CDCl}_{3}$ with $\mathrm{Me}_{4} \mathrm{Si}$ as an internal standard. Elemental analysis were carried out on Carlo-Erba-Analyser Model 1104. IR spectra were recorded on a Bruker IFS-25 spectrophotometer. The calix(4)arene 1 was prepared according to the published procedure [10].

\section{Procedure for the preparation of $\mathbf{2}$}

To a solution of $10 \mathrm{~g}(12.9 \mathrm{mmol}) \mathbf{1}$ in dichloromethane $(50 \mathrm{~mL})$ and glacial acetic acid $(30 \mathrm{~mL})$, $63 \% \mathrm{HNO}_{3}(5 \mathrm{~mL})$ was added dropwise at $-15^{\circ} \mathrm{C}$ in 2 min and the reaction mixture was then stirred at room temperature for $4 \mathrm{~min}$ and poured into water $(250 \mathrm{~mL})$. The organic layer was extracted with dichloromethane $(2 \times 100 \mathrm{~mL})$, the solvent was removed and solid residue was dissolved in methanol (100 
$\mathrm{mL}$ ), concentration of solution to a volume of ca. $50 \mathrm{~mL}$ led to the appearance of a pale yellow precipitate (yield 85\%). The product thus obtained was pure enough for subsequent reactions but could be further purified by recrystallization from a mixture of dichloromethane and methanol; $\mathrm{mp} 182-184^{\circ} \mathrm{C}$.

IR $v_{\text {max }}(\mathrm{KBr}) / \mathrm{cm}^{-1} 3456,1592,1472,1334,1201,1006 ; \delta \mathrm{H}\left(400 \mathrm{MHz} ; \mathrm{CDCl}_{3}\right) 0.83[18 \mathrm{H}, \mathrm{s}$, $\left.\left.\mathrm{C}\left(\mathrm{CH}_{3}\right)_{3}\right)\right], 0.95\left[3 \mathrm{H}, \mathrm{t}, \mathrm{CH}_{3}\right], 1.10\left[6 \mathrm{H}, \mathrm{t}, \mathrm{CH}_{3}\right], 1.35\left[9 \mathrm{H}, \mathrm{s}, \mathrm{C}\left(\mathrm{CH}_{3}\right)_{3}\right], 1.93\left[4 \mathrm{H}, \mathrm{m}, \mathrm{CH}_{2}\right], 2.2[2 \mathrm{H}, \mathrm{m}$, $\mathrm{CH}_{2}$ ], 3.19 and 4.34[4H, d of d, J=12.6 Hz, $\mathrm{ArCH}_{2} \mathrm{Ar}$ ], 3.75[2H, t, $\mathrm{OCH}_{2}$ ], 3.81[ 4H, t, $\mathrm{O} \mathrm{CH}_{2}$ ], 3.39 and 4.31[4H, d of d, J=13.9 Hz, $\left.\mathrm{ArCH}_{2} \mathrm{Ar}\right], 6.45[2 \mathrm{H}, \mathrm{d}, \mathrm{J}=2.3 \mathrm{~Hz}, \mathrm{ArH}], 6.60[2 \mathrm{H}, \mathrm{d}, \mathrm{J}=2.3 \mathrm{~Hz}, \mathrm{ArH}$, 7.16[2H, s, ArH], 7.22[1H, s, OH], 8.06[2H, s, ArH]; $\delta \mathrm{C}(100 \mathrm{MHz}) 9.56,10.70,22.55,23.37,31.10$, 31.36, 31.47, 31.68, 33.74, 34.15, 58.46, 76.15, 78.01, 124.31, 125.68, 125.70,129.80, 132.65, 135.76, 139.34, 145.82, 151.75, 153.78, 159.98; M/Z (FD) 764(m $\left.{ }^{+}, 100 \%\right)$. Anal. Calcd for $\mathrm{C}_{49} \mathrm{H}_{65} \mathrm{NO}_{6}: \mathrm{C}$, $77.06 \% ; \mathrm{H}, 8.52 \% ; \mathrm{N}, 1.84 \%$. Found C, 76.8\%, H, 8.7\%; N, 2.2\%.

Procedure for the preparation of $\mathbf{3}$ and $\mathbf{4}$

To a solution of $2 \mathrm{~g}(2.58 \mathrm{mmol}) \mathbf{1}$ in dichloromethane $(25 \mathrm{~mL})$ and acetic anhydride $(4 \mathrm{~mL})$ at $-10^{\circ} \mathrm{C}$, $63 \% \mathrm{HNO}_{3}(1 \mathrm{~mL})$ was added in $2 \mathrm{~min}$ and the reaction mixture was then stirred at room temperature for $5 \mathrm{~min}$ and poured into water $(250 \mathrm{~mL})$. The organic layer was extracted by dichloromethane $(2 \times 100 \mathrm{~mL})$, the solvent was removed and the solid residue was dissolved in methanol $(100 \mathrm{~mL})$, concentration of solution to ca. $50 \mathrm{~mL}$ led to a white precipitate. 3 is obtained as a white crystals in $63 \%$ separated yield (crystallized from a mixture of $\mathrm{CH}_{2} \mathrm{Cl}_{2}$ and $\mathrm{CH}_{3} \mathrm{OH}$ ). mp, 214-217 ${ }^{\circ} \mathrm{C} ; 4$ was purified by column chromatography of the mother liquors (silicagel, $\mathrm{CH}_{2} \mathrm{Cl}_{2}$, n-hexane, 1:4); yield $22 \% \mathrm{mp}, 225$ $228^{\circ} \mathrm{C}$.

Spectral data for $\mathbf{3}$

IR $v_{\max }(\mathrm{KBr}) / \mathrm{cm}^{-1} 3510,1598,1513,1343$ and $1014 . \delta \mathrm{H}\left(400 \mathrm{MHz} ; \mathrm{CDCl}_{3}\right) 0.86[18 \mathrm{H}, \mathrm{s}$, $\left.\mathrm{C}\left(\mathrm{CH}_{3}\right)_{3}\right], 0.97\left[3 \mathrm{H}, \mathrm{t}, \mathrm{CH}_{3}\right], 1.11\left[6 \mathrm{H}, \mathrm{t}, \mathrm{CH}_{3}\right], 1.94\left[4 \mathrm{H}, \mathrm{m}, \mathrm{CH}_{2}\right], 2.22\left[2 \mathrm{H}, \mathrm{m}, \mathrm{CH}_{2}\right], 3.35$ and $4.42\left[4 \mathrm{H}, \mathrm{d}\right.$ of d, J=12.9 Hz, $\left.\mathrm{ArCH}_{2} \mathrm{Ar}\right], 3.78\left[4 \mathrm{H}, \mathrm{t}, \mathrm{OCH}_{2}\right], 3.96\left[2 \mathrm{H}, \mathrm{t}, \mathrm{OCH}_{2}\right], 3.43,4.29[4 \mathrm{H}, \mathrm{d}$ of d, $\left.\mathrm{J}=13.8 \mathrm{~Hz}, \mathrm{ArCH}_{2} \mathrm{Ar}\right], 6.56[4 \mathrm{H}, \mathrm{s}, \mathrm{ArH}], 7.37[1 \mathrm{H}, \mathrm{s}, \mathrm{OH}], 8.07[2 \mathrm{H}, \mathrm{s}, \mathrm{ArH}], 8.10[2 \mathrm{H}, \mathrm{s}, \operatorname{ArH}] ; \delta \mathrm{C}($ $100 \mathrm{MHz}) 9.48,10.66,22.44,23.40,33.01,31.13,31.43,33.87,76.67,78.15,124.12,124.46,125.28$, 125.46, 129.43, 130.30, 130.98, 138.06, 140.10, 143.05, 146.64; 151.83, 159.70, 164.05; M/Z (FD) 753(m+ $\left.\mathrm{m}^{+}, 100 \%\right)$. Anal. Calcd for $\mathrm{C}_{45} \mathrm{H}_{56} \mathrm{~N}_{2} \mathrm{O}_{8}: \mathrm{C}, 71.79 \% ; \mathrm{H}, 7.50 \% ; \mathrm{N}, 3.72 \%$. Found $\mathrm{C}, 71.5 \%, \mathrm{H}$, $7.5 \% ; \mathrm{N}, 3.1 \%$.

Spectral data for 4

IR $v_{\max }(\mathrm{KBr}) / \mathrm{cm}^{-1} 3508,1592,1521,1341$ and 1005. $\delta \mathrm{H}\left(400 \mathrm{MHz} ; \mathrm{CDCl}_{3}\right) 0.74[9 \mathrm{H}, \mathrm{s}$, $\left.\mathrm{C}\left(\mathrm{CH}_{3}\right)_{3}\right], 0.92\left[3 \mathrm{H}, \mathrm{t}, \mathrm{CH}_{3}\right], 1.12\left[3 \mathrm{H}, \mathrm{t}, \mathrm{CH}_{3}\right], 1.13\left[3 \mathrm{H}, \mathrm{t}, \mathrm{CH}_{3}\right], 1.40\left[9 \mathrm{H}, \mathrm{s}, \mathrm{C}\left(\mathrm{CH}_{3}\right)_{3}\right], 1.90[2 \mathrm{H}, \mathrm{m}$, $\left.\mathrm{CH}_{2}\right], 2.08\left[2 \mathrm{H}, \mathrm{m}, \mathrm{CH}_{2}\right], 2.23\left[2 \mathrm{H}, \mathrm{m}, \mathrm{CH}_{2}\right], 3.21$ and $4.40\left[2 \mathrm{H}, \mathrm{d}\right.$ of d, J=13.1 Hz, $\left.\mathrm{ArCH}_{2} \mathrm{Ar}\right], 3.25$ and $4.30\left[2 \mathrm{H}, \mathrm{d}\right.$ of d, J=13.0 Hz, $\left.\mathrm{ArCH}_{2} \mathrm{Ar}\right], 3.42$ and $4.46\left[2 \mathrm{H}, \mathrm{d}\right.$ of d, J=13.7 Hz, $\left.\mathrm{ArCH}_{2} \mathrm{Ar}\right], 3.51$ and $4.20\left[2 \mathrm{H}, \mathrm{d}\right.$ of d, J=14.5 Hz, $\left.\mathrm{ArCH}_{2} \mathrm{Ar}\right], 3.77\left[6 \mathrm{H}, \mathrm{m}, \mathrm{OCH}_{2}\right], 6.17[1 \mathrm{H}, \mathrm{s}, \mathrm{OH}], 6.45[1 \mathrm{H}, \mathrm{d}, \mathrm{J}=2.1 \mathrm{~Hz}$, $\operatorname{ArH}], 6.51[1 \mathrm{H}, \mathrm{d}, \mathrm{J}=2.1 \mathrm{~Hz}, \mathrm{ArH}], 7.21[1 \mathrm{H}, \mathrm{d}, \mathrm{J}=2.3 \mathrm{~Hz}, \mathrm{ArH}], 7.22[1 \mathrm{H}, \mathrm{d}, \mathrm{J}=2.6 \mathrm{~Hz}, \mathrm{ArH}], 7.24[1 \mathrm{H}$, d, J=2.2 Hz, ArH], 7.27[1H, d, J=2.6 Hz, ArH], 8.11[1H, d, J=2.5 Hz, ArH], 8.14[1H, d, J=2.5 Hz, 
$\operatorname{ArH}] ; \delta \mathrm{C}(100 \mathrm{MHz})$ 9.43, 10.69, 10.71, 22.52, 23.34, 23.46, 30.63, 30.80, 31.05, 31.08, 31.63, $34.01,34.30,76.45,77.63,78.24,122.31,123.51,124.30,124.66,124.77,125.88,126.72$, $126.77,128.64,128.77,129.94,133.56,133.78,134.80,135.08,136.00,139.93,142.81,146.78$, 147.54, 150.68, 153.79, 159.31, 161.73; M/Z (FD) 753(m+, 100\%). Anal. Calcd for $\mathrm{C}_{45} \mathrm{H}_{56} \mathrm{~N}_{2} \mathrm{O}_{8}: \mathrm{C}$, $71.79 \% ; \mathrm{H}, 7.50 \%$; N, 3.72\%. Found C, 71.6\%, H, 7.5\%; N, 3.1\%.

Acknowledgements: Parviz Rashidi-Ranjbar is grateful to the Research Council of Tehran University for financial support. Generous support from Prof. Dr. J. Ipaktschi, Institute of Organic Chemistry, Giessen University is highly acknowledged. The Ministry of Culture and Higher Education of Iran is acknowledged for a grant to S. T-G.

\section{References and Notes}

1. Gutsche, C. D.; Levine, J. Am. Chem. Soc. 1982, 104, 2652.

2. Merkushev, E. B. Synthesis 1988, 923.

3. Mogch, L.; Böhmer, B.; Fergusen, G.; Vogt, W. J. Chem. Soc, Perkin Trans, 1 1996, 1711.

4. No, K.; Noh, Y. Bull. Korean Chem. Soc. 1986, 7, 314.

5. Van Loon, J. D.; Arduini, A.; Coppi, L.; Verboom, W.; Pochini; A.; Ungaro, R.; Harkema, S.; Reinhoudt, D. N. J. Org. Chem. 1990, 55, 5639.

6. Verboom, W.; Durie, A.; Egberink, R. J. M.; Asfari, Reinhoudt, D. N. J. Org. Chem. 1992, 57, 1313.

7. Bitter, I.; Gruen, A.; Toth, G.; Szoellosy, A.; Horvath, G.; Agai, B.; Toke, L. Tetrahedron 1996, $52,636$.

8. Mogck, O.; Parzuchowski, P.; Nissinen, M.; Boehmer, V.; Rokicki, G.; Rissanen, K. Tetrahedron 1998, 54, 10053.

9. Fischer, C.; Nieger, M.; Mogck, O.; Boehmer, V.; Ungaro, R.; Voegtle, F. Eur. J. Org. Chem. 1998, 155.

10. Iwamoto, K.; Araki, K.; Shinkai, S. Tetrahedron 1991, 47, 4325.

Sample Availability: Available from the authors.

(C) 2000 by MDPI (http://www.mdpi.org). 